MARTIN PREMK, kustos

Vojaški muzej Slovenske vojske

Slovenija, Maribor, Engelsova 15

UDK 355.48/.49(497.4)"1991"

\title{
SPOPAD JNA I SLOVENSKE TERITORIJALNE OBRAMBE V LJUBLJANSKI POKRAJINI 1991.
}

\begin{abstract}
APSTRAKT: Članak je plod iscrpnog istraživanja ratnih događaja u Ljubljanskoj pokrajini tokom kratkotrajnog rata u Sloveniji 1991. godine. Pisan je na osnovu arhivskih podataka kao i literature, u kojima su objavljena sećanja slovenačkih aktera tih događaja.
\end{abstract}

Ključne reči: Jugoslavija, Slovenija, JNA, Teritorijalna obramba, Ljubljana

Teritorialna obramba Ljubljanske pokrajine (oziroma 5. Pokrajinskega štaba TO) je obsegala osrednje območje Slovenije in območje glavnega mesta Ljubljane in okolice in je krazen na TO Vzhodnoštajerske pokrajine mejila na vse ostale pokrajine TO Slovenije. Območje delovanja 5. PŠTO Ljubljanske pokrajine je bilo izrednega pomena, saj je bilo v glavnem mestu Ljubljani zbrano osrednje politično vodstvo Slovenije ter vse najpomembnejše politične ustanove (parlament, vlada, ministrstva), v Ljubljani pa je bil tudi sedež Republiškega štaba TO. V Ljubljani so bile tudi druge ustanove izrednega pomena (radio-televizija, pošta, klinični center itd), območje Ljubljane pa je tudi osrednje vozlišče Slovenije, kjer se križajo vse cestne in železniške povezave in kjer je osrednje mednarodno letališče na Brniku.

\section{Začetek vojne v Ljubljanski pokrajini}

Delovanje JLA na področju Ljubljanske pokrajine se je, po predhodnih pripravah s prihodom okrepitev in premestitvijo poveljujočih, dejansko začelo že 26. junija 1991, ko sta vojašnico Ivan Cankar na Vrhniki zapustila dva voda izvidniških tankov PT-76B in oklepnih avtomobilov BRDM-2 iz Izvidniške čete 1. oklepne brigade. Izvidniški tanki in oklepni avtomobili so se ta dan premaknili do Ljubljane in Kranja, kjer so bili nato podrejeni 61. obmejnemu odseku oziroma 345. gorski brigadi, ki jih je uporabila za zaprtje mejnih prehodov Rateče, Korensko sedlo, Hrušica, Ljubelj in Jezersko. Čeprav so vrhniški teritorialci že takrat želeli postaviti barikade in preprečiti nadaljnje odhode iz vojašnic, so jim iz republiške koordinacije ta predlog zavrnili. Sicer je podkoordinacijska skupina 
za Ljubljansko pokrajino že $\mathrm{v}$ začetku junija sprejela načrt, da $\mathrm{v}$ primeru izpada enot JLA iz Vrhnike te blokira $\mathrm{z}$ ustavitvijo živega prometa ${ }^{1}$ in ceste blokira $\mathrm{z}$ vozili, kar bi lahko v kratkem času naredila milica. ${ }^{2}$

Takoj po razglasitvi samostojnosti zvečer 26. junija 1991 so enote JLA začele delovati v skladu z načrti. V 1. oklepni brigadi na Vrhniki so ob polnoči na 27. junij 1991 odprli kuverte $z$ navodili 5. vojaškega območja JLA. V ukazu je bilo zapisano, da mora 1. oklepni bataljon 1. oklepne brigade ob 2.3027 . junija 1991 v dveh kolonah napredovati k letališču Brnik, ga blokirati in onemogočiti njegovo delovanje, ter preprečiti posredovanje slovenskih notranjih organov ter Teritorialne obrambe. Po ukazu se je 1. oklepni bataljon, ki je bil sestavljen iz 1 . in 2. tankovske čete (v vsaki je bilo 10 tankov M-84) ter mehanizirane čete (10 bojnih vozil BVP-M80A) in poveljniških ter zalednih vozil razdelil na dve koloni, ki je vsaka napredovala po svoji vnaprej začrtani smeri. V „desni koloni“ je bila 1. tankovska četa z 10 tanki $\mathrm{M}-84,{ }^{3} 1$. in 3 . vod mehanizirane čete s šestimi bojnimi vozili BVP M-80A, poveljniški oklepni transporter BTR-50, dva tovornjaka za zaledno oskrbo, sanitetno vozilo ter manjše poveljniško vozilo. Koloni je poveljeval namestnik poveljnika bataljona kapetan Radomir Rosić, ki je bil v poveljniškem oklepnem transporterju BTR-50, v manjšem poveljniškem vozilu pa sta bila še brigadni načelnik zvez major Frane Radobuljac in brigadni načelnik varnosti kapetan Rade Popović. V „levi koloni“ je bila 2. tankovska četa z 10 tanki M-84, 2. vod mehanizirane čete s štirimi bojnimi vozili BVP M-80A, ${ }^{4}$ bojno vozilo BVP M-80A poveljnika bataljona ${ }^{5}$ ter tovornjak za zaledno oskrbo. Tej koloni je poveljeval poveljnik 1. oklepnega bataljona major Danilo Radovanović. ${ }^{6}$

„Leva kolona“" je imela ukaz do Brnika priti prek Vrhnike, Loga, Brezovice, Dobrave, mimo Toškega čela in prek Šentvida, „,desna kolona“ pa po avtocesti od Vrhnike do Ljubljane, prek zahodne ljubljanske obvoznice, prek Črnuč, Mengša, Trzina in Most pri Komendi. Ob koloni sta vojašnico Ivan Cankar na Vrhniki začeli zapuščati ob 2.40 zjutraj. „Leva kolona“ je na prvo barikado, ki jo je postavila Posebna enota milice pod poveljstvom Staneta Leskovška, naletela

${ }^{1} \mathrm{Na}$ podkoordinacijski skupini je bil sprejet predlog Marjana Starca, da se v primeru izpada iz vojašnice „Ivan Cankar“ naredi blokado iz „tekočega prometa“ iz 5-6 vrst vozil in dolgo približno 300-400 metrov, ki bi se lahko postavila v nekaj minutah. Zavrnjen pa je bil predlog podpolkovnika Miha Butare, da bi v bližini vojašnice postavili dežurne ekipe s težko gradbeno mehanizacijo, ker bi s tem vznemirjali JLA in prebivalstvo ter motili delovene procese v organizacijah, ki bi morale zagotovit tovornjake ter drugo gradbeno mehanizacijo. Sanja Remškar: Občina Vrhnika v času vojne za Slovenijo (1991) (Ljubljana, 2007), 73.

${ }^{2}$ Sanja Remškar: Občina Vrhnika v času vojne za Slovenijo (1991) (Ljubljana, 2007), 73-74; VMSV, ZA, fond 1991, škatla 9: Izvajanje b/d 1. okbr - analiza, Komanda 1.okbr, št. 12061, 13. 8. 1991.

${ }^{3} \mathrm{~V}$ četi so bili trije vodi s tremi tanki M-84 in tank poveljnika čete.

${ }^{4}$ Trije BVP M-80A iz drugega voda ter BVP M-80A poveljnika mehanizirane čete.

${ }^{5}$ To vozilo so vzeli namesto pokvarjenega poveljniškega tanka T-55K.

${ }^{6}$ Sanja Remškar: Občina Vrhnika v času vojne za Slovenijo (1991) (Ljubljana, 2007), $71-72$. 
pri Brezovici. Barikado, ki je bila narejena iz nekaj osebnih vozil, so oklepna vozila prebila in prevozila, pri čemer se je tovornjaku za zaledno oskrbo prevrnila zadaj pripeta poljska kuhinja, en tank M-84 pa se je ustavil zaradi okvare. „Leva kolona“" je nato odšla naprej proti Dobrovi in proti Podutiku in Šentvidu, kjer je del vozil zgrešil pravo smeri in zavil proti vrhu Toškega čela. Ko so opazili napako, je med obračanjem en tank M-84 zdrsnil s ceste, drugi je obstal ob cesti, z njima pa je nato na cesti ostal še tretji tank, verjetno zaradi zavarovanja je tako tam ostal ves vod tankov M-84. Ostali del kolone je nadaljeval pot in prebil še eno blokado, sestavljeno iz avtobusov. Nato je kolona zavila na Celovško cesto ter nadaljevala pot do Šentvida, kjer so ob postavljenih tovornjakih zavili na avtocesto in nadaljevali pot proti Kranju. Na poti so obvozili še eno blokado, ki jo je postavila milica in ob 5.35 prišli do Brnika, kjer so se razvrstili po položajih v gozdu nasproti vhoda na letališče. „Desna kolona“ je na Vrhniki zavila na avtocesto in napredovala do cestninske postaje na Logu, ki so jo delno zaprli z barikado, ki jo je kolona obvozila po levi strani. Za cestninsko postajo Log je pri Brezovici med mostom čez avtocesto in izvozom za Brezovico obstal pokvarjen tank M-84, ki ni mogel več voziti. Pri razcepu Kozarje pri Brdu je kolona naletela na novo barikado, ki so jo tanki in bojna vozila obšli tako, da so zapeljali na nasprotni pas avtoceste. Barikade pa ni uspelo obvoziti tovornjakoma za zaledno oskrbo in sanitetnemu vozilu. Ostala kolona je nadaljevala pot proti Trzinu, kjer so naleteli na novo barikado. ${ }^{7}$

\section{Spopad v Trzinu}

Pri mostu čez potok Pšata je domžalska milica, ki je spremljala napredovanje kolon, postavila barikado iz avtomobilov in tovornjakov. Malo pred četrto uro zjutraj 27. junija 1991 se je „desna kolona“ pripeljala pred barikado v Trzinu, kjer se je za kratek čas ustavila. Po kratkem ogledu barikade so se odločili za preboj in so barikado s tanki M-84 brez večjih težav prebili. Ker se je za barikado zaradi zaprte ceste nabralo že več vozil, so pot nadaljevali po travniku mimo vozil. Večina kolone je prevozila barikado, dokler ni bojno vozilo BVP M-80A pri zavijanju s cestišča na travnik zadelo ob betonsko ogrado mostu in si pretrgalo gosenico. Večina „desne kolone“ kolone s tanki M-84 in bojnimi vozili BVP M80 je nadaljevala pot do Brnika, kjer je zasedla položaje, en tank $M-84^{8}$ pa je ok-

\footnotetext{
${ }^{7}$ Sanja Remškar: Občina Vrhnika v času vojne za Slovenijo (1991) (Ljubljana, 2007), 71-72.

${ }^{8}$ Tank je posadka zapustila, nato pa je tank zagorel in eksplodiral. Posadko je zajela 30. razvojna skupina, po nepreverjenih podatkih naj bi v zapuščeni tank najprej streljali pripadniki TO z raketometi Armbrust, ki pa tanka niso poškodovali, nato naj bi tank zažgali. Pripadniki TO so zajeli ali onesposobili tudi ostale tanke 1. bataljona 1. okbr, ki so zaostali na poti: Vod tankov M-84, ki je zašel na Toškem čelu, so posadke 27. Junija 1991 zapustile in se umaknile v vojašnico na Vrhniki. Na tank M-84, ki je ostal na avtocesti pri Brezovici, pa so pripadniki TO 29. junija 1991 izstrelili dve raketi Armbrust. Tank M-84 je bil dvakrat zadet v bok, vendar oklep ni nbil prebit, posadka pa se je nato predala.
} 
varjen ostal ob cesti pri Komendi. Bojno vozilo BVP M-80A, ki je ostalo v Trzi$\mathrm{nu}$, se je poskušalo izvleči ter si je s tem zapletlo gosenico med nosilna kolesa. Tako je zaprlo pot zadnjemu delu kolone, v kateremu sta bili še dve bojni vozili BVP M-80A ter malo terensko vozilo, ki so ga uporabljali kot malo poveljniško vozilo. Pri barikadi je tako obstal celoten 3. vod mehanizirane čete 1. oklepnega bataljona pod poveljstvom višjega vodnika Tomislava Bakračevića, ki je štel tri bojna vozila BVP M-80A in 30 vojakov $^{9}$ in podčastnikov, ter malo poveljniško vozilo $\mathrm{z}$ radijskimi napravami, $\mathrm{v}$ katerem sta bila poleg vojaka in voznika še načelnik za zveze v poveljstvu 1. oklepne brigade major Frane Radobuljac ter častnik varnostne službe JLA (KOS - kontraobveščevalna/ protiobveščevalna služba) kapetan Rade Popović.

V pristojnem 55. ObmŠTO Domžale so bili že okoli 6.30 ure zjutraj 27. junija 1991 obveščeni, da se kolona bojnih vozil pomika proti Brniku ter da so v Trzinu obstala tri bojna vozila BVP M-80A in poveljniško vozilo. Vse podatke so posredovali v 5. PŠTO, kjer sta bila na zvezi poveljnik 5. PŠTO podpolkovnik Miha Butara in poveljnik 55. ObmŠTO stotnik Marjan Mahnič. Kmalu pa je bil v Trzinu tudi protioklepni vod 2. jurišnega odreda TO, ves čas so vojake v barikadi spremljali miličniki in vojaki TO, naredili pa so tudi nove barikade, ki so vozilom onemogočale premik naprej ali nazaj. Vojaki vseh treh bojnih vozil so se trudili popraviti BVP M-80A s poškodovanim hodnim delom, medtem pa so domačini na vojake gledali vse bolj sovražno in se zbirali okoli barikade.

O vsem kar se je dogajalo, je načelnik za zveze major Frane Radobuljac prek radijske zveze obveščal poveljnika 1. oklepne brigade. Nekaj po 11. uri je načelnik štaba 5. PŠTO stotnik Vojko Pavlin po telefonu sporočil ukaz poveljnika 5. PŠTO podpolkovnika Miha Butare, da je potrebno obkoljena vozila z ustreznimi enotami TO obkoliti, začeti pogajanja, jih razorožiti ter zapleniti orožje in tehnična sredstva, poveljevanje nad enotami TO pa naj prevzame načelnik štaba 55. ObmŠTO stotnik Bojan Končan. Ukazano je bilo tudi, naj se poveljujočemu enotam TO v Trzinu Bojanu Končanu doda tudi protioklepni vod 2. jurišnega odreda TO s 16 protioklepnimi raketometi Armbrust, ki je bil v bližini. Ukaz je sprejel poveljnik 55. ObmŠTO stotnik Marjan Mahnič ter za izvedbo naloge določil Protidiverzatski vod TO Kamnik pod poveljstvom stotnika Igorja Kvasa, ki je štel 24 mož, Diverzanstski vod TO Kamnik pod poveljstvom stotnika Boža Zupančiča, ki je štel 23. mož in okrepljen vod Zaščitne čete TO Domžale s 30 možmi pod poveljstvom stotnika Janeza Gregorčiča. Vse tri enote TO so bile oborožene z lahkim pehotnim orožjem, protioklepni vod, ki je že bil v Trzinu, pa s protioklepnimi raketometi Armbrust.

Za pogajalce z blokiranimi vojaki JLA so bili določeni načelnik 55. ObmŠTO stotnik Bojan Končan, major Anton Železnik in stotnik Edvard Golob.

\footnotetext{
${ }^{9}$ Bojno vozilo BVP M-80A ima tričlansko stalno posadko in sedem pehotnih vojakov v zadnjem delu.

${ }^{10}$ Ladislav Gjergjek: Vojaški spopad v Trzinu leta 1991 (Ljubljana, 2007), 30-32.
} 
Vse določene tri enote TO so se zbrale ob12. 30 na dvorišču tovarne LEK pri Zgornjih Jaršah, o prihodu na zborno mesto je stotnik Bojan Končan poročal poveljniku stotniku Marjanu Mahniču, ki mu je takrat tudi odobril uporabo dveh protioklepnih raketometov Armbrust. Izpred tovarne Lek v Zgornjih Jaršah so se vse tri enote odpeljale na dvorišče osnovno šole v Trzinu, kjer so se izkrcali iz vozil. Stotnik Bojan Končan je poveljnikom razdeli naloge, nato so vse tri enote odšle na svoje določene položaje.

Diverzantski vod TO Kamnik je zasedel položaje ob železniški progi Ljubljana - Kamnik na južni strani blokiranih vozil JLA. Proti diverzantski vod TO Kamnik je zasedel položaje pod vznožjem hriba Onger $(378 \mathrm{~m})$ severno od Trzina. Vod Zaščitne čete TO Domžale pa je zasedel položaje pri severno-vzhodno pri osnovni šoli Trzin. Vse tri enote so bile na položajih okoli 13. ure, tam pa niso imele več zveze s poveljstvom ali medsebojne zveze, ker so bili brez radijskih postaj.

Takoj po obkolitvi vozil JLA je stotnik Bojan Končan odšel na pogajanja s kapetanom Radetom Popovićem in majorjem Franetom Radobuljcem, ki sta bila poveljujoča častnika JLA. Oba sta bila zelo živčna, kapetan KOS Rade Popović pa tudi nadut in odločen. Pri pogajanjih je bil občasno prisoten tudi poveljnik 3. voda mehanizirane čete višji vodnik Tomislav Bakračević, ki se prav tako obnašal vzvišeno in odločno. Kapetan Rade Popović je odločno zavrnil predajo, predlagal pa je umik vozil s cestišča, češ da bi tako sprostili cesto. Ponujeno mu je bilo, da se lahko umakne le, če vojaki izročijo osebno oborožitev s strelivom ter če izročijo strelivo za topove $20 \mathrm{~mm}$ na bojnih vozilih BVP M-80A. To je kapetan Rade Popović zavrnil in prek radijske zveze o vsem obvestil poveljnika 1. oklepne brigade, ki je ob 13. 30 od poveljnika 14. korpusa prvič zahteval uporabo helikopterskega desanta za deblokiranje bojnih vozil v Trzinu.

Približno v tem času je tudi poveljnik RŠTO polkovnik Janez Slapar od poveljnika 5. PŠTO podpolkovnika Mihe Butare zahteval, naj v obkolitev v Trzinu vključi tudi enoto Specialne enote milice pod poveljnikom inšpektorjem Vinkom Beznikom. Ob približno 14. 20 je okoli 20 pripadnikov SEM pod poveljstvom inšpektorja Vinka Beznika brez najave prišlo na območje Trzina. O prihodu pripadnikov SEM pa pred tem niso obvestili poveljujočega stotnika Bojana Končana in seveda tudi ostalih pripadnikov enot TO na tem območju. Zato so bili pripadniki TO presenečeni, ker pa se je stotnik Bojan Končan poznal s inšpektorjem Vinkom Beznikom, je stotnik Končan pritekel do inšpektorja Beznika in vzpostavil stik. Nato ga je seznanil s položajem enot TO in razmerami v blokadi. Inšpektor Vinko Beznik je nato razporedil približno 20 svojih miličnikov, oboroženih s pehotnim in protioklepnim orožjem, na položaje Proti diverzantskega voda TO Kamnik neposredno ob cesti severno zahodno od blokade ter na položaje južno od blokade. Po dogovoru s pripadniki SEM so se pripadniki proti diverzantskega voda umaknili nekoliko nazaj med hiše. Stotnik Bojan Končan se je skupaj s inšpektorjem Vinkom Beznikom ponovno pogajal s kapetanom Radetom Popovićem, in čeprav sta bila kapetan Popović in inšpektor Beznik znanca, ga nista uspela prepričati $\mathrm{v}$ predajo. 
Ob približno 14.50 se je v bližino blokade spustil helikopter SA 341 (Soko H.42) „Gazela“, ki je obkoljenim vojakom JLA pripeljal hrano in vodo. Ker je bil neoborožen, so mu pripadniki TO in SEM dovolili pristati, čeprav sta se bila v njem tudi častnik in podčastnik JLA, ki sta imela nalogo izvidovanja. Helikopter je čez nekaj minut odletel, položaj pa je postajal vedno bolj napet, saj ni bilo videti, da bi se vojaki JLA hoteli predati. Inšpektor Vinko Beznik in stotnik Bojan Končan sta se začela dogovarjati o napadu, ki naj bi ga naredili tako, da bi pripadniki TO s protioklepnim raketometom Armbrust uničili prvo bojno vozilo, pripadniki SEM pa bi uničili zadnja dva bojna vozila in malo poveljniško vozilo. Poveljnik enote SEM inšpektor Vinko Beznik je med tem prek radijske zveze dobil obvestilo, da JLA pripravlja desant za osvoboditev obkoljenih vojakov, ki naj bi ga izvedli pripadniki diverzantskega odreda ${ }^{11}$ s helikopterji Mi-8. S tem je seznanil stotnika Bojana Končana, ki je odšel do stotnika Radeta Popovića in mu dejal, da bodo v primeru prihoda helikopterjev pripadniki TO začeli streljati, ta pa se je pretvarjal, da o prihodu helikopterjev ne ve nič. Inšpektor Vinko Beznik je nato prek radijske zveze dobil ukaz, da naj strelja in uniči vozilo za zveze. S tem je seznanil tudi stotnika Radeta Popovića, vendar zaradi nadaljevanj pogajanj do niso izvršili tega ukaza.

Ob približno 17. 45 so nad Trzinom zakrožili trije helikopterji JLA, ki so nato odleteli proti Ljubljani. Ker so v Diverzantskem vodu TO Kamnik zaslutili, da bi se $\mathrm{v}$ primeru helikopterskega desanta na njivah vzhodno od Trzina znašli med obkoljenimi vojaki JLA in desantom, se polovico pripadnikov umaknili bolj jugo - vzhodno od Trzina. Diverzantski vod TO Kamnik je tudi prevzel nalogo boja proti predvidenemu helikopterskemu desantu, kar sta se dogovorila tudi stotnik Bojan Končan ter namestnik poveljnika enote SEM, ki je nadomestil inšpektorja Vinka Beznika, ki je moral oditi na novo nalogo. Novo nalogo in položaje je poveljniku Diverzantskega voda TO Kamnik določi stotnik Bojan Končan. Ob približno 18.30 so ponovno prileteli trije helikopterji. Kmalu nato sta se ob 18.38 dva helikopterja Mi -8 spustila na njive med Trzinom in Depalo vasjo približno 250 metrov za železniško progo. Iz helikopterjev se je izkrcalo 27 pripadnikov diverzantskega odreda JLA, ki jim je poveljeval kapetan Duško Popović. Kmalu nato je prišlo do streljanja med pripadniki diverzantskega odreda JLA in pripadniki TO.

Stotnik Bojan Končan je ukazal vojaku Dušanu Mihaliču iz protioklepnega voda 2. jurišnega odreda TO naj s protioklepnim raketometom Armbrust strelja na helikopter. Prvi Armbrust, ki ga je vzel Dušan Mihalič, se ni hotel sprožiti, zato je vzel drugega in z njim ustrelil proti helikopterju, vendar je izstrelek zadel ob veje in predčasno eksplodiral. Helikopterje so začeli obstreljevati tudi s pehotnim orožjem, zato sta oba helikopterja hitro odletela. Vnel se je splošen spopad med pripadniki TO in SEM ter vojaki JLA v blokiranih bojnih vozilih in

11 „Specialci“ oziroma diverzanti, ki so prišli nekaj dni pred tem v Slovenijo prišli iz Skopja, so bili pripadniki Diverzantskega odreda 3. vojne oblasti JLA iz Skopja. 
vojaki diverzantskega odreda. Vojaki JLA iz diverzantskega odreda so se poskušali prebiti do obkoljenih vojakov v bojnih vozilih, ki so tudi začeli streljati iz vozil. Med močnim ognjem so se pripadniki Diverzantskega voda TO začeli umikati proti staremu delu Trzina, med umikom je bil ob 18.45 smrtno zadet pripadnik Diverzantskega voda TO Kamnik Edvard Peperko. Stotnik Bojan Končan in Dušan Mihalič sta ste umaknila $\mathrm{v}$ hišo ob cesti za železniško progo, kjer sta s podstrešja „uspešno odbijala napade“. Vrata hiše pa je varoval sin lastnika hiše, ki mu je stotnik Bojan Končan dal svojo avtomatsko pištolo.

Pred desantom se je čez cesto umaknila tudi skupina pripadnikov SEM na južni strani blokade, ki se je znašla v navskrižnem ognju. Proti vrhu hriba Onger so se umaknili tudi pripadniki Proti diverzantskega voda TO Kamnik, ker so pričakovali nov desant in obkolitev, nato pa se kmalu vrnili na kraj spopada. V pričakovanju novega desanta so se proti hribu Onger umikali tudi pripadniki voda zaščitne čete TO Domžale.

Med vojaki JLA v obkoljenih bojnih vozili in pripadniki TO in milice $\mathrm{v}$ Trzinu se je medtem vnel splošni spopad. Iz bojnih vozil BVP M-80A so s topom $20 \mathrm{~mm}$ streljali po okolici in med drugim zažgali vozila $\mathrm{v}$ barikadi. Na prvo bojno vozili BVP M-80A je pripadnik SEM izstrelil dva raketometa Armbrust in ga uničil. Pri tem sta bila mrtva dva vojaka JLA, tretji vojak pa je bil ubit med streljanjem, ko je skočil iz vozila. Drugi BVP M-80A se je poskušal premaknili, a je kmalu zapeljal na betonsko ploščo greznice, ki se je vdrla, tako da je vozilo obstalo. Po dveh uspešnih zadetkih iz „Armbrustov“ v bojno vozilo in streljanju je bilo poškodovano tudi malo poveljniško vozilo. Še en vojak JLA je bil ubit med streljanjem, ko je poskušali priti od bojnih vozil do diverzantskega odreda JLA. Vojaki JLA so se začeli predajati, prvi se je predal ob 19.24, nato so se začeli predajati tudi ostali, spopad pa je bil končan ob 19.38. Vojaki diverzantskega odreda JLA so se začeli umikati proti Depali vasi, tako da je streljanje dokončno potihnilo okoli 20.30 ure. Iz Trzina so se po končanih spopadih umaknili tudi pripadniki SEM in vojaki Proti diverzantskega voda TO Kamnik, stotnik Bojan Končan je odšel v 55. ObmŠTO poročat o dogodkih v Trzinu.

Zajete vojake JLA je s seboj odpeljala SEM, razen štirih vojakov, ki so jih v naglici pustili v Trzinu. Te štiri vojake JLA so nato domačini sami odpeljali na postajo milice v Črnuče. V Trzinu je ostal le vod Zaščitne čete TO Domžale, ki se je razporedil na nove položaje na obrobje hriba Onger. Iz 55. OBmŠTO pa so na območje Trzina poslali še Jurišni odred TO Kamnik. Poveljnik voda Zaščitne čete TO Domžale stotnik Janez Gregorič je še s štirimi pripadniki TO začel pregledovati bojišče in pobirati orožje pri dveh zajetih bojnih vozilih. Pri tem je naletel še na tretji BVP M-80A, v katerem je bil poveljnik mehaniziranega voda višji vodnik Tomislav Bakračević in devet vojakov. Bojno vozilo s celotno posadko je po spopadu neopaženo ostalo v Trzinu in čakalo nadaljnji razplet dogodkov. Domačini v Trzinu so to opazili in sporočil naprej, tako da je bil o bojnemu vozilu obveščen tudi 5. PŠTO, kjer so ukazali 55. ObmŠTO zajetje bojnega vozila in vojakov. Proti Trzinu je nato odšel Jurišni odred TO Kamnik, ki naj bi nada- 
ljeval boj proti oklepnim vozilom in novim napadi JLA. Poveljnik voda Zaščitne čete TO Domžale stotnik Janez Gregorič se je ob navzočnosti domačina Jakoba Franjiča začel pogajati z vojaki v vozilu. Kmalu nato se v Trzin iz 55. ObmŠTO Domžale vrnil stotnik Bojan Končan, ki je dobil nalogo, da poskrbi za štiri ujete vojake, ki jih je tam pustila SEM in so jih medtem že odpeljali domačini. Stotnik Janez Gregorič se je, ker ni vedel kdo prihaja, takrat umaknil stran od bojnega vozila. Ko so stotnik Bojan Končan, stotnik Edvard Golob, Dušan Mihalič in Dominik Koritnik približali bojnemu vozilu, so iz vozila izstrelili rafal. Tudi oni so ugotovili, da je v bojnem vozilu posadka, ki se še ni predala, o tem pa jih še ni obvestil nihče, prav tako pa niso vedeli niti za prejšnja pogajanja s stotnika Janeza Gregoriča s posadko vozila. Stotnik Bojan Končan je začel nova pogajanja s posadko vozila, kmalu pa sta se ponovno pridružila tudi stotnik Janez Gregorič in Jakob Franjič, ter še nekaj drugih pripadnikov TO in domačinov. Posadki so prinesli hrano in vodo ter jo prepričali, da nima smisla vztrajati. Približno ob 22.30 se je predal še tretji BVP M-80A s poveljnikom 3. voda mehanizirane čete višjim vodnikov Tomislavom Bakračevičem in devetimi vojaki.

Vojaki diverzantskega odreda JLA so se medtem zatekli v hišo Staneta Koritnika pri Depali vasi. Med umikanjem so zajeli tri talce, Iztoka Seničarja, Vlada Seničarja in Camara Jantulaja, ki so izstopili iz vlaka v Trzinu. Iztok Seničar in Camar Jantulaj sta morala poskrbeti za mrtvega in ranjenega vojaka, ki ga je nato odpeljal rešilni avtomobil, ki so ga poklicali. Iztoka Seničarja in Camara Jantulaja so nato izpustili, Vlada Seničarja pa odvedli s seboj. Rešitev talcev je od poveljnika 5. PŠTO Mihe Butare zahteval tudi Miha Brejc iz varnostno informativne službe. Vojaki diverzantskega odreda JLA so nato do 4. ure zjutraj ostali v hiši Staneta Koritnika, ki so jo razdejali in oropali, nato pa so se razdelili na tri skupine in se skrili v gozdu v okolici hiše. Skupine so se nato ponovno združile, medtem pa se je Vladu Seničarju uspelo rešiti. Vse vojake diverzantskega odreda so nato obkolili miličniki SEM, ki so z njimi začeli pogajanja. Med tem so vojake diverzantskega odred iskali helikopterji JLA, vendar jih niso uspeli pobrati. Okoli 11.30 se je vseh 26 vojakov diverzantskega odreda pod poveljstvom kapetana Duška Popovića predalo SEM. ${ }^{12}$

V spopadu je umrl pripadnik TO Edvard Peperko ter vojaki JLA iz 1. oklepne brigade: Slobodan Stojkovič, Ratko Jovanović, Dušan Peno in Domagoj Sotinac. V Klinični center v Ljubljani je bilo nato prepeljano 17 ranjencev, od tega 8 pripadnikov TO, med katerimi je bil huje ranjen v glavo Aleš Kodra, en pripadnik SEM, dva civilista ter šest vojakov JLA. Eden od ranjencev je nato po devetih dneh umrl v kliničnem centru. ${ }^{13}$

${ }^{12}$ Ladislav Gjergjek: Vojaški spopad v Trzinu leta 1991 (Ljubljana, 2007), 35-52; Miro Sobočan in Miha Butara: Segmenti iz delovanja ljubljanske TO v letu 1991 (Ljubljana, 1993), 24-30.

${ }^{13}$ Ladislav Gjergjek: Vojaški spopad v Trzinu leta 1991 (Ljubljana,2007), 52-53; Matjaž Veselko: Kirurška oskrba poškodovanih v spopadu v Trzinu in poškodovance, oskrbljenih v UKC Ljubljana med junijsko vojno (Ljubljana, 1992), 104-110. 
O samem spopadu so v 55. ObmŠTO napisali: „Pogajanja so potekala organizirano in dokaj strokovno. Razmerje sil je bilo v korist nasprotnika. Odobrena količina protioklepnih sredstev (2 Armbrusta) proti trem OT in vozilu za zveze je bila nerealna. Do prihoda pripadnikov SEM smo bili brez vsakršne zveze in podatkov o namerah nasprotnika. Šele po prihodu pripadnikov SEM smo začeli dobivati podatke o prihodu nasprotnikovih helikopterjev, za obrambo in notranje zadeve kar je bistveno pripomoglo k našim odločitvam in ukrepanju. Vodenje naših enot je bilo organizirano na osebnih kontaktih med poveljniki enot in NŠ 55 . ObmŠTO, ki je koordiniral potek akcije s poveljnikom SEM, kar pa je bilo zelo naporno, saj se je sama taktika uporabe naših enot menjala iz minute v minuto." ${ }^{\text {(14 }}$

\section{Blokada Ljubljane in vojašnic v Ljubljanski pokrajini TO}

Nemudoma po odhodu tankov iz vrhniške vojašnice so pripadniki Teritorialne obrambe in milice s pomočjo civilnih republiških ustanov začeli s postavljanjem barikad, s katerimi so hoteli preprečiti napredovanje tankov, predvsem pa vdor tankov v središče Ljubljane. Že 27. junija 1991 je bilo postavljenih 59 blokad na vpadnicah v Ljubljano ali pa v središču mesta, kjer so barikade postavili predvsem okoli pomembnih objektov, kot so Predsedstvo Republike Slovenije in vladna palača, Radio-televizije Slovenije in Cankarjevega doma, v katerem je bila po 29. juniju 1991 tudi Republiška koordinacija. Barikade so sestavili iz priročnih sredstev, predvsem iz tovornjakov, avtobusov, gradbene mehanizacije in osebnih vozil. Pripadniki TO so minirali devet barikad, pomagali pa so si tudi s plinskimi jeklenkami in peskom, ki so jih namestili v barikade. Kmalu po postavitvi barikad so se pojavile težave z zasebnimi lastniki vozil v barikadah, še večje težave pa so začeli povzročati vozniki tovornjakov iz tujine in drugih republik bivše Jugoslavije. Največ tovornjakov je ostalo na Dolenjski cesti, voznikom pa je bilo treba zagotoviti hrano ali jih oddaljiti iz barikad. Po nekaj dnevih so iz barikad začeli umikati tuja vozila ter vozila z živino in nevarnimi snovmi. Vozila $\mathrm{v}$ barikadah so tudi začeli nadomeščati s kovinskimi španskimi jezdeci in betonskimi tetraedri. Barikade so iz ljubljanskih vpadnic začeli umikati med 8. in 10. julijem 1991, ko so z barikadami pustili zavarovano le središče Ljubljane s Predsedstvom republike Slovenije in vlado. ${ }^{15}$

Najpomembnejše vojašnice in smer proti Vrhniki so varovale enote 5. PŠTO. Kot največjo nevarnost za Ljubljano so ocenili vojašnico Boris Kidrič v Šentvidu. V njej je bilo poveljstvo 14. proletarske motorizirane brigade (s 1. bataljonom ter mešanim artilerijskim divizionom), 289. bataljon vojne policije $\mathrm{z}$ oklepnimi vozili BOV-VP in vojaki Diverzantskega odreda GŠ JLA. V vojašnici

${ }^{14}$ Vojaški muzej Slovenske vojske, zbirka arhivalij, fond Obrambna vojna 1991, škatla 9 (dalje: VMSV, ZA, fond 1991): Analiza bojnega delovanja TO 55. ObmŠTO Domžale v času od 26. 6 do 15. 7. 1991, poročilo 55. ObmŠTO za 5. PŠTO št. 804-03/36-91 z dne 17. 7. 1991.

${ }^{15}$ Janez Švajncer: Obranili domovino (Ljubljana, 1993), 119. 
je bilo poleg težke oborožitve mešanega artilerijskega diviziona (devet havbic $105 \mathrm{~mm}$, devet havbic $155 \mathrm{~mm}$, minometi $120 \mathrm{~mm}$ ) tudi ogromno težkega orožja iz velikih skladiščnih prostorov, ki so bili v sklopu vojašnice.

Ob začetku vojne so se vojaki pod poveljstvom polkovnika Tomislava Šipčića začeli pospešeno utrjevati v vojašnici in pripravljati obrambne položaje, težko orožje pa so razmestili na položajih znotraj vojašnice. Prvi dan vojne je polkovnik Tomislav Šipčić po telefonu zagrozil predsedniku Izvršnega sveta občine Šiška Petru Zuletu, da bo v primeru kakršnega koli napada na vojašnico odgovoril z vso razpoložljivo močjo. Polkovnik Šipčić je grozil, da bo v primeru napada na vojašnice streljal iz vsega artilerijskega orožja, ki je že namerjeno na Predsedstvo in Izvršni svet republike Slovenije ter zgradbo skupščine, prav tako pa bo streljal na ljubljansko plinarno, naprave ljubljanskega vodovoda, transformatorske postaje, Kemično tovarno Moste ter tovarni Color v Medvodah in Belinka v Dolu.

Grožnje polkovnika Tomislava Šipčića je predsednik Izvršnega sveta občine Šiška Peter Zule takoj posredoval načelniku štaba 51. ObmŠTO majorju Franciju Kunovarju. Poleg napada $\mathrm{z}$ težkim orožjem je grozila tudi nevarnost izpada oklepnih vozil iz motorizirane brigade ter vojakov vojne policije JLA iz vojašnice Borisa Kidriča proti centru Ljubljane. Zaradi pomembnosti blokade vojašnice Borisa Kidriča in razbremenitve 51. ObmŠTO je bilo ustanovljeno operativno poveljstvo ${ }^{16}$ za blokado vojašnice, ki mu je poveljeval Brane Podgoršek, poveljnik 2. Odreda TO ki je izvajal neposredno blokado vojašnice. ${ }^{17}$

Veliko nevarnost za Ljubljano je bila tudi vojašnica „Bratstvo in enotnost" $\mathrm{v}$ Mostah, kjer je bil nameščen 635. lahki protiletalski polk in druge enote, ki bi ravno tako lahko delovale po Ljubljani. Operativno poveljstvo nad enotami TO na območju ljubljanskih Most je prevzel Neven Borak, ki je bil sicer poveljnik 1. odreda TO.

V blokado vojašnice „Bratstvo in enotnost“ so bile takoj po začetku spopadov poslane enote 5. PŠTO, ki so se že pred začetkom spopadov usposabljale v bližini vojašnice, nato pa se premaknile na bojne položaje in zavarovale vojašnico in širšo okolico vojašnice. Enote TO so zavarovale predvsem smeri proti zahodu $\mathrm{v}$ notranjost Ljubljane ter prometnice proti severu, kamor bil lahko enote JLA odšle na pomoč proti Brniku. ${ }^{18}$

Enote 51. ObmŠTO so skupaj s pripadniki milice zavarovale tudi ostale vojašnice in objekte JLA v Ljubljani. Del enot je nadziral predvsem vojašnico „Ljubo Šercer“ na takratni Titovi cesti, vojašnico „4. julij“ na Metelkovi cesti in „Maršal Tito“ na Roški cesti, del enot pa je bil v pripravljenosti za hitro posredo-

${ }^{16}$ Operativna poveljstva so bila oblikovana pri vseh blokadah vojašnic.

${ }^{17}$ Janez Švajncer: Obranili domovino (Ljubljana, 1993), 118; Miro Sobočan in Miha Butara: Segmenti iz delovanja ljubljanske TO v letu 1991 (Ljubljana, 1993), 39-41.

${ }^{18}$ Janez Švajncer: Obranili domovino (Ljubljana, 1993), 118; Miro Sobočan in Miha Butara: Segmenti iz delovanja ljubljanske TO v letu 1991 (Ljubljana, 1993), 41. 
vanje. Velik del enot 51. ObmŠTO je bil razporejen tudi na območju Viča, kjer je varoval smer iz Vrhnike proti Ljubljani, kjer je bilo pričakovati morebiten nov prodor enot 1. oklepne brigade JLA. Tako so bile na območju Brezovice oziroma križišča pri „Paviljonu“ razmeščene naslednje enote 51. ObmŠTO. Na širšem območju Tržaške ceste in na območju Kosez, Rožne doline in Živalskega vrta je bil razmeščen 3. odred TO ki je varoval smer proti centru do zgradbe občine Vič na začetku Tržaške ceste. Za zaščito, zveze in preskrbo so bile na območju Viča oziroma na Tbilisijski cesti razmeščeni še Izvidniški oddelek TO Vič, Zaščitna četa TO Vič, Oddelek za zveze TO Vi in Zaledni oddelke TO Vič. Blokade proti Vrhniki so enote 51 . ObmŠTO zavarovale tudi s protioklepnimi minami in drugimi minsko-eksplozivnimi sredstvi, tudi z jeklenkami plina. ${ }^{19}$

Ko so bile vse ljubljanske vojašnice in vojaški objekti nadzorovani in blokirani, so v 5. PŠTO dobili ukaz o napadu na vse ljubljanske vojašnice. Poveljnik RŠTO polkovnik Janez Slapar je 28. junija 1991 prek telefonske zveze sporočil poveljniku 5. PŠTO podpolkovniku Mihi Butari, naj enote 5. PŠTO napadejo vse vojašnice v Ljubljani in na Vrhniki, „da se bo streljalo in pokalo.“ Podpolkovnik Miha Butara je ukaz zavrnil ${ }^{20}$ in zahteval pisni ukaz, ki pa ga nikoli ni dobil. Poveljnik RŠTO polkovnik Janez Slapar je nato ukaz o napadu na ljubljanske in vrhniške vojašnice mimo poveljstva 5. PŠTO pošiljal v enote 5. PŠTO, pri čemur je uporabljal šifro „Sonce“, ki je bila tajno ime poveljnika 5. PŠTO podpolkovnika Mihe Butare. Enote, ki so dobile ta ukaz, ga niso izvršile. ${ }^{21}$

Do smrtne žrtve pri barikadah pa je prišlo na Aškerčevi ulici pri Filozofski fakulteti v Ljubljani, kjer so varovali Predsedstvo RS v Cankarjevemu domu. Miličniki so tam 30. junija 1991 ob 00.22 uri ustavili vozilo Zastava 101. Ko se je vozilo ustavilo, je voznik začel streljati in je s streli ubil miličnika Stanka Straška. Voznik, ki je bil pripadnik 30. razvojne skupine TO, je nato pobegnil po takratni Titovi cesti proti Bežigradu, kjer so ga poskušali ustaviti in je bil med streljanjem ubit. ${ }^{22}$

${ }^{19}$ Miro Sobočan in Miha Butara: Segmenti iz delovanja ljubljanske TO v letu 1991 (Ljubljana, 1993), 39-41; VMSV, ZA, fond 1991, škatla 9: Prehrana (namestitev) enot 51. ObmŠTO na dan 30. 6. $1991 \mathrm{ob} 22.00$. dokument 51. ObmŠTO, 30. 6. 1991.

${ }^{20}$ Polkovnik Janez Slapar navaja, da ni šlo za ukaz za napad temveč za ukaz za priprave za napad in da podpolkovnik Miha Butara ukaza ni zavrnil oziroma odklonil, temveč da ga ni izvršil. Janez Slapar: „Za poštenost in resničnost“ v: Vojnozgodovinski zbornik št.8/2002, (Logatec, 2002) 4-6.

${ }^{21}$ Poveljnik Odreda 1. partizanske brigade TO stotnik Neven Borak, ki je s svojo enoto izvajal blokado vojašnice „Bratstvo in enotnost“ v Mostah, tudi ni hotel izvršiti ukaza. Za katerega je misli, da prihaja neposredno od poveljnika 5. PŠTO in se je nato povezal s poveljstvom 5. PŠTO. Podpolkovnik Miha Butara je stotniku Nevenu Boraku pojasnil, da tega ukaza ni izdal on in obvestil tudi vse ostale poveljnike, naj ukaza ne upoštevajo, ter da lahko bojna dejstva izvajajo le po ukazu poveljnika 5. PŠTO ali če so neposredno napadeni strani JLA. Sanja Remškar: Občina Vrhnika v času vojne za Slovenijo (1991) (Ljubljana, 2007), 86-87; Miha Butara: Zgrozil sem se ob ukazu, v: Slovenska panorama (Ljubljana, 14. 6. 2000), 5-6.

${ }^{22}$ Biserka Debeljak: Muzej organov za notranje zadeve (Ljubljana, 2006), 249; Miha Butara, ustna izjava. 
Vojašnice v Ljubljani so ostale pod nadzorom tudi po prekinitvi ognja 3. julija 1991 in 51. ObmŠTO so 6. in 7. julija 1991 vpoklicali in oblikovali celotno 1., 2. in 3. partizansko brigado TO 51. ObmŠTO, ki so prevzemale varovanje ljubljanskih vojašnic.

Po izpadu tankov 1. oklepne brigade JLA so dodatno zavarovali tudi vojašnico „Ivan Cankar“. Po Vrhniki so postavili barikade, s katerimi so zaprli vse možne smeri izhoda oklepnih vozil iz Vojašnice. Največjo blokado so postavili pri križišču dovoza $\mathrm{z}$ avtocesto pri bencinski črpalki, $\mathrm{v}$ njej je bilo več tovornjakov, avtobusov in drugih vozil. V sami Vrhniki so barikade postavili še pri Gasilskem domu, ob vojašnici na Robovi cesti, na Betajnovi in pri Skupščini občine Vrhnika. Zunaj Vrhnike pa so barikade postavili na mostu čez Ljubljanico proti Verdu in v Verdu pri mostu čez Ljubijo ter v Bistri (da preprečijo dostop do skladišča v Borovnici), pri nadvozu nad avtocesto pri Sinji Gorici in na začetku klanca proti Logatcu. Vse barikade so nato minirali, minirali pa so tudi kolovoz med Tunjščico in Podlipščico, po kateremu se je zjutraj v vojašnico vrnil tank M-84, ki se je pokvaril pri Brezovici. Dopoldne pa sta po tej poti krenila tudi tank za izvleko TZI in tank M-84, ki sta verjetno hotela do okvarjenega tanka M-84 na avtocesti pri Brezovici. Tank za izvleko je kmalu nato zapeljal na mino, ki mu je uničila gosenico. Oba tanka so pozivali k predaji, vendar so vojaki JLA čez noč tank popravili, nato sta se oba tanka naslednji dan vrnila v vojašnico. Poleg blokade je Skupščina občina Vrhnika takoj prvi dan sprejela tudi sklepe, da se vrhniškim vojašnicam prekine dobavo vode in elektrike ter uporabo telefona ter prepove dostavo hrane do vojašnic. Vojašnici „Ivan Cankar" so tudi odrekli pravico do imena Ivan Cankar. Medtem ko so vodo vojašnici Ivana Cankarja hitro uspešno odklopili, so vodovodni jašek do vojašnice „Ignaca Voljča“ vojaki JLA nato zavarovali in preprečili zaprtje vode. Ker so z zaprtjem vode vojašnici „Ivana Cankarja“ zaprli tudi vodo večjemu delu Vrhnike, so nato vodo priklopili nazaj. ${ }^{23}$

Tanki iz vojašnice „Ivan Cankar“ so že prvi dan vojne tudi zasedli vrh Sv. Trojice nad Vrhniko, od koder so imeli pregled nad mestom. Četa desetih tankov M-84 je po vzpetini zavzela obrambne položaje in imela pregled nad celotnim področjem. Republiška koordinacije je zahtevala napad na tanke, vendar so iz 53. ObmŠTO in 5. PŠTO možnost napada zavrnili, saj zaradi prevelike razdalje in neprimernega terena niso mogli učinkovito napasti tankov. O možnosti napada na Vrhniko s položajev na Sv. Trojici pa so razmišljali tudi v 1. oklepni brigadi. S tanki so hoteli streljati na zgradbo občine Vrhnika, vendar so si premislili, ker bi s tem porušili več zgradb in bi bile v nevarnosti tudi družine častnikov JLA. Oziroma kot so zapisali v sami 1. okleni brigadi: „V konzultaciji ožjega dela poveljstva brigade smo prišli do zaključka, da tako rušenje objektov na Vrhniki lahko negativno vpliva na starešinsko sestavo, ker je bilo ta čas v stanovanjih

${ }^{23}$ Sanja Remškar: Občina Vrhnika v času vojne za Slovenijo (1991) (Ljubljana, 2007), $73-76$. 
okoli 300 članov naših družin. Bilo bi dosti bolj učinkovito, če bi z enim bataljonom šli v Vrhniko in zavzeli vse pomembne objekte ter zaščitili naše družine.“24

Takoj po začetku spopadov je bila obkoljena tudi vojašnica oziramo skladišče v Grosupljem, ki so jo obkolile enote 57. ObmŠTO. Poleg blokade vojašnice v Grosupljem so enote 57. ObmŠTO tudi zavarovale vse prometnice in pomembne smeri na svojem območju. To so bile predvsem smeri Grosuplje-Ljubljana in Litija-Ljubljana ter druge smeri. Glavni namen zavarovanja smeri proti Ljubljani je bil zaustavitev enot JLA obkoljenih na Medvedjeku, če bi jim tam uspelo prebiti blokado. $\mathrm{V}$ tem primeru so bile enote 57 . ObmŠTO pripravljene preprečiti nadaljnje prodiranje v smeri Ivančna Gorica-Grosuplje-Škofljica. Namen nadzora in varovanja ozemlja je bila tudi preprečitev morebitnega prodora enot JLA iz Vrhnike proti Grosupljemu. Vojašnica v Grosupljem je bila ves čas blokirana in pod nadzorom enot 57. ObmŠTO. Narejen je bil sicer načrt za napad na vojašnico, vendar zaradi nevarnosti razstrelitve skladišč z velikimi količinami orožja in minsko-eksplozivnih sredstev do napada ni prišlo oziroma je bil ukaz za napad preklican. Na obkoljene častnike in vojake JLA v vojašnici Grosuplje so ves čas pritiskali z raznimi sredstvi in jim prekinjali dobavo hrane in elektrike. Poveljnik 57. ObmŠTO Miloš Šonc je bil ves čas v stikih s poveljnikom vojašnice, med vojaki so ves čas na razne načine poskušali ustvariti preplah in padec bojne zavesti. Tako je $\mathrm{v}$ dneh obkolitve iz vojašnice $\mathrm{v}$ Grosupljem pobegnilo 18 vojakov JLA, ki so se predali enotam 57 . ObmŠTO. ${ }^{25}$

\section{Zavzetje skladišča pri Borovnici}

Poleg vasi Brezovica pri Borovnici je imela JLA večje skladišče orožja, streliva, minsko-eksplozivnih sredstev in druge vojaške opreme. Varovala ga je 1. oklepna brigada z Vrhnike, v skladišču pa je bilo orožje, strelivo, oprema tako za enote JLA, predvsem za 1. oklepno brigado in za oborožitev lahke divizije JLA, kot tudi orožje slovenske TO. Poleg skladišča je imela JLA tu tudi farmo prašičev. Skladišče je varovalo 34 vojakov pod poveljstvom častnika JLA, za varovanje so imeli tudi sedem psov.

Skladišče pri Borovnici je dopoldne 28. junija 1991 opazoval 2. izvidniški vod 30. razvojne skupine TO pod poveljstvom Roka Hrovatina. V 2. izvidniškem vodu so se samostojno odločili za akcijo in med opazovanjem so zajeli dva vojaka iz skladišča, ki sta se oblečena v civilne obleke odpravila proti Borovnici. Odpeljali so ju na zaslišanje, kjer sta se predstavila kot vojak in desetar, ter pove-

${ }^{24}$ Miro Sobočan in Miha Butara: Segmenti iz delovanja ljubljanske TO v letu 1991 (Ljubljana, 1993), 36-37; VMSV, ZA, fond 1991, škatla 9: Izvajanje b/d 1. okbr - analiza, Komanda 1.okbr, št. 1206-1, 13. 8. 1991.

${ }^{25}$ VMSV, ZA, fond 1991, škatla 9:Analiza bojnega delovanja TO 57. ObmŠTO Grosuplje v času od 26. 6 do 15. 7. 1991, poročilo 57. ObmŠTO za 5. PŠTO; Miloš Šonc: „Delovanje v 57. Območnem štabu za Teritorialno obrambo (ObmŠTO) Grosuplje v času osamosvojitvene vojne 1991“.v: Zbornik ZVVS - Grosuplje, (Grosuplje, 2006), 23-26. 
dala kakšno je stanje in koliko je vojakov v skladišču. Zagrozili so jima, naj vojake v skladišču prepričata $\mathrm{v}$ predajo, drugače bodo skladišče napadli in raketirali. Desetar je prosil, da ga spustijo nazaj, da prepriča vojake v predajo. Kmalu mu je to tudi uspelo in vojaki v skladišču so se brez odpora predali pripadnikom 2. izvidniškega voda 30. razvojne skupine. Med tem, ko so se vojaki predajali, je pobegnil drugi ujeti vojak, ki je bil v resnici aktivni poročnik JLA. Med pobegom je bil ranjen ter se je kasneje pri skladišču spet predal pripadnikom TO.

Tudi po zavzetju skladišča zgodaj popoldne 28. junija 1991 so s pomočjo slovenskega vojaka iz skladišča vzdrževali telefonsko zvezo z vojašnico na Vrhniki. Da je skladišče pri Borovnici zavzeto, so v 5. PŠTO izvedeli nekaj po 16. uri ter ukazali 53. ObmŠTO, da skladišče zavaruje ter prepreči morebiten prodor enot JLA do skladišča. V Republiški koordinaciji pa so v zvezi z zavzetjem ukazali, da je potrebno vsa sredstva iz skladišča odpeljati, skladišče pa pripraviti za razstrelitev. Za koordinatorja te naloge je bil določen Ludvik Zvonar, vodja uprave za zaledno oskrbo pri RSLO in predstavnik Republiške koordinacije pri 5. PŠTO, ki je odšel tudi sam v skladišče.

Kmalu po 17. uri so v skladišče prišli tovornjaki iz 5. PŠTO, ki jih je vodil pomočnik za zaledje 5. PŠTO stotnik 1. st. Miran Barborič. Nalagati so jih začeli s pomočjo pripadnikov voda delovne obveze, ki so ga mobilizirali v oddelku za ljudsko obrambo na Vrhniki, in ki so že čakali v gasilskem domu v Brezovici pri Borovnici: prvi tovornjaki, naloženi s protioklepnim in protiletalskim orožjem so proti Ljubljani odpeljali okoli 20. ure, z njimi so odpeljali tudi zajete vojake JLA. Ves tovor so morali vmes preložiti na tovornjake $\mathrm{z}$ večjo nosilnostjo. Tovornjaki so ostalo orožje in sredstva odpeljali na železniško postajo Moste, od koder so orožje in sredstva začeli razvažati naprej po Sloveniji, ne da bi ga uredili in popisali, čeprav je na železniški postaji Moste to zahteval tudi poveljnik 5. PŠTO podpolkovnik Miha Butara. Naložili so še nov transport tovornjakov, okoli 23. pa so dobili sporočilo, da se Borovnici približujejo tanki JLA. Takrat so odpeljali naložene tovornjake, umaknilo se je tudi okoli 50 pripadnikov voda delovne obveze in 2 . izvidniški vod 30 . razvojne skupine, tako da je skladišče ostalo nezavarovano.

Zjutraj 29. junija 1991 je v skladišče prišla tudi četa iz 511. odreda TO za posebne namene pod poveljstvom Janeza Čerina, ki je prevzela varovanje. S to enoto s prejšnji večer okrepili zavarovanje smeri Borovnica - Vrhnika in Borovnica - Ljubljana, ko so pričakovali prihoda enot JLA. Po prihodu je Janez Čerin zavaroval skladišče in začel z nadzorom širšega območja okrog skladišča. Razmere v skladišču so bile neurejene, kljub temu pa so še ta dan in naslednje dni nadaljevali z nalaganjem tovornjakov in odvažanjem orožja in drugih sredstev iz skladišča. Skladišče je bilo varovano do 2. julija 1991, ko je iz 5. PŠTO prišel ukaz, da mora četa 511. odreda TO oditi na Vrhniko in pomagati 53. ObmŠTO pri zaustavitvi izpada tankov iz vojašnice Ivana Cankarja in novih napadov JLA. V skladišče so se vrnili šele naslednji dan, med tem pa naj bi na skladišče pazili le pripadniki Narodne zaščite. Ob prihodu v skladišče 3. julija 1991 so po priče- 
vanju poveljnika Janeza Čerina naleteli na „obupno stanje“. V oddelku za ljudsko obrambo Vrhnika so nato naslednje dni pozivali okoliške prebivalce, naj vrnejo iz skladišča odvzeto orožje in sredstva. V naslednjih dneh pa so v skladišče še naprej prihajali tovornjaki iz vseh delov Slovenije, ter še naprej odvažali orožje in sredstva. Z orožjem iz skladišča pri Borovnico so okrepili enote TO iz vse Slovenije, čeprav je odvoz orožja potekal neorganizirano in brez ustreznega popisa odpeljanega orožja in sredstev. V skladišče je 6. julija 1991 pripeljala tudi kolona tovornjakov z zagrebškimi registracijami, ki so jo spremljali pripadniki TO, med njimi tudi pomočnik za zaledje iz RŠTO Anton Vereš. Ko so tovornjake naložili so odpeljali v smeri proti Ljubljani. Obsežno skladišče pri Borovnici, kjer so bila poleg orožja in opreme tudi minsko-eksplozivna sredstva in strelivo, so praznili do 14. julija 1991. ${ }^{26}$

\section{Zavzetje prisluškovalnega centra na Rožniku}

Na Šišenskem hribu (429 m) na pobočju Rožnika nad Ljubljano je imela JLA prisluškovalni center oziroma center za elektronska dejstva. Namenjen je bil prisluškovanju v tujino ter opremljen $\mathrm{z}$ radijskimi in elektronskimi sredstvi, iz njega so lahko prisluškovali in ovirali tudi zvezam v notranjosti oziroma zvezam republiškega vodstva in TO. Ukaz za zavzetje prisluškovalnega centra na Rožniku je 28. junija 1991 poveljnik 5. PŠTO podpolkovnik Miha Butara posredoval načelnik varnostno obveščevalne službe Andrej Lovšin v imenu ministra za obrambo.

Nalogo zavzetja prisluškovalnega centra je zaupal stotniku 1. st. Miroslavu Debelaku in ga z ukazom seznanil približno ob 16.00 uri 28. junija 1991 ob prisotnosti predstavnika Republiške koordinacije Ludvika Zvonarja. Stotniku Miroslavu Debelaku so bila dana natančna navodila, kako zavzeti center na Rožniku brez uporabe strelnega orožja, ker niso želeli poškodovati elektronskih naprav v centru. Streljanje pa bi lahko ogrozilo tudi prebivalce Ljubljane, saj je bil prisluškovalni center na Šišenskem hribu tik nad ljubljanskimi stanovanjskimi naselji v Šiški. Orožje se bil lahko uporabilo le v skrajnem primeru, tako da bi se razstrelilo stražarnico centra.

Za nalogo je bilo določeno šest vojakov Voda vojaške policije 5. PŠTO ter dvanajst vojakov Zaščitne čete 5. PŠTO, ki jih je izbral stotnik Miroslav Debelak, preveril pa načelnik štaba 5. PŠTO stotnik Vojko Pavlin. Oboroženi so bili $\mathrm{z}$ avtomatskim strelnim orožjem in protioklepnimi raketometi Armbrust. Poleg njih je bil za nalogo določen tudi vezist iz 5. PŠTO, da bi takoj po zavzetju ocenil elektronska sredstva in njihovo nadaljnjo uporabo, ter dva pripadnika (Brane Praznik in Rajko Janša) varnostne službe, eden od njiju je bil zadolžen za snemanje dogajanja $\mathrm{z}$ videokamero. Med pripravami na nalogo so podrobne podatke o sta-

${ }^{26}$ Miro Sobočan in Miha Butara: Segmenti iz delovanja ljubljanske TO v letu 1991 (Ljubljana, 1993), 49-51; Sanja Remškar: Občina Vrhnika v času vojne za Slovenijo (1991) (Ljubljana, 2007), 81-85; Janez Švajncer: Obranili domovino (Ljubljana, 1993), 119-121. 
nju in dogajanju v centru na Rožniku dobili od civilista, ki je bil v centru zaposlen in so ga pred tem ujeli v parku Tivoli. Izvedeli so, da je vzdušje med osebjem v centru klavrno, ker se jih večina ne strinja s početjem JLA ter da bi se verjetno hitro predali. Upiral bi se verjetno lahko le poveljujoči častnik JLA in nekaj njegovih sodelavcev.

Priprave na zavzetje so bile končane okoli 18.00 ure, tako da je skupina za zavzetje približno ob 18.30 prišla pod vznožje Rožnika. Pod poveljstvom stotnika Miroslava Debelaka so začeli obkoljevati prisluškovalni center iz dveh smeri ter ga obkolili ob približno 18.50 , pozorni so bili tudi, da jih iz centra niso opazili ter da jih ni opazil tudi pes, ki so ga v centru imeli za varovanje. Ko so center obkolili in nadzirali, so v center poslali civilista, da bi svoje sodelavce prepričal v predajo. Stotnik Miroslav Debelak je določil rok za predajo ob 19.07, drugače bo $\mathrm{z}$ raketometom Armbrust razstrelil stražarnico, katero so nadzirali tudi z ostrostrelno puško.

Kmalu za tem so se ob približno 19.00 pri vhodu v center prikazali trije vojaki v bojni opremi, ki so se želeli predati. Odšli so do stotnika Debelaka, ki jih je pozval, naj dvignejo roke, nato so jih prevzeli pripadniki TO na položajih okrog centra. Za njimi je pred vhod prišla večja skupina vojakov in civilist, ki so se prav tako želeli predati. Med njimi pa ni bilo poveljujočega častnika JLA, zato je stotnik Debelak zagrozil, da bo razstrelil zgradbo, če se ne preda še on. Vojaki JLA so ga začeli glasno nagovarjati, da naj se preda, nakar je iz zgradbe prišel še poveljujoči častnik JLA. Vse vojake so razorožili in zajeli, poveljujočega častnika JLA je razorožil sam stotnik Debelak. Nato so začeli pregledovati poslopja, pri pregledu je sodeloval tudi poveljujoči častnik JLA. Med pregledom so posumili in nato ugotovili, da je častnik JLA obotavljal s predajo zato, da je lahko nadrejenim javil, da so jih napadli, kar je nato priznal tudi častnik JLA.

$\mathrm{V}$ prisluškovalnem centru so zajeli 20 vojakov in poveljnikov JLA z osebno oborožitvijo in opremo. Dogajanje so ves čas snemali z videokamero. Vojake so odpeljali v 5. PŠTO, kjer so jih zaslišali, iz centra so odpeljali tudi 3 radijske sprejemnike, spektralni analizator, dva kratkovalovna sprejemnika ter nekaj druge opreme. V 5. PŠTO so med tem dobili zahtevo namestnika načelnika RŠTO podpolkovnika Daniela Kuzme, naj se skupina umakne z Rožnika, češ da tja prihajajo „specialci JLA“, ki naj bi jih poklali z noži, ter da je v prisluškovalni center poslana tudi enota SEM pod poveljstvom Vinka Beznika. Skupina pod vodstvom stotnika Miroslava Debelaka se je zato nekaj po 21. uri dokončno umaknila z Rožnika, čeprav je obstajala nevarnost, da se v nastajajočem mraku srečajo s prihajajočimi pripadniki SEM, za katere tudi niso vedeli, po kateri poti bodo šli do prisluškovalnega centra na Šišenskem hribu na Rožniku. V izpraznjeni prisluškovalni center so nato ponoči prišli pripadniki SEM, ki so po zgradbah streljali in deloma uničili opremo v centru. ${ }^{27}$

${ }^{27}$ VMSV, ZA, fond 1991, škatla 9: Poročilo Miroslava Debelaka za 5. PŠTO, Ljubljana, 16. 7. 1991; Miro Sobočan in Miha Butara: Segmenti iz delovanja ljubljanske TO v letu 1991 (Lju- 


\section{Poskus preboja tankov iz Vrhnike proti Logatcu in Sinji Gorici}

V vojašnici Ivan Cankar je tudi po odhodu 1. oklepnega bataljona ostal večji del 1. oklepne brigade, ki je 2. julija 1991 začela z novimi napadi. V 1. oklepni brigadi so dobili nalogo, da se 2. julija 1991 2. oklepni bataljon iz Vrhnike premakne do Logatca, kjer naj bi z eno četo zasedel položaje na Pustem polju pri Logatcu in z drugo v vasi Kalce. V sklopu te naloga je bil tudi premik 1. tankovske čete 3. oklepnega bataljona iz Vrhnike do Sinje Gorice, kjer naj bi četa zavzela položaje pri Sinji Gorici. ${ }^{28}$

Pred izpadom oklepnih enot sta ob 15.45 nad Vrhniko prileteli dve letali Mig - 21, ter začeli raketirati in obstreljevati barikade. Napadeni sta bili predvsem barikadi pri bencinski črpali na Vrhniki in barikada v Sinji Gorici. Na letali je streljala skupina za protizračno obrambo z Bevk z raketo Strela2M, vendar letal niso zadeli, s pehotnim orožjem pa so na letela streljali tudi drugi pripadniki TO. Med napadi sta letali razstrelili in zažgali tovornjake in avtobuse $\mathrm{v}$ barikadah, ranjeni so bili štirje domačini, ki so se po naključju nahajali v bližini barikad. Vse ranjence so po koncu napadov hitro oskrbeli in prepeljali v bolnišnico, gasilci pa so začeli z gašenjem tovornjakov in avtobusov, čeprav so bile v bližini gorečih vozil tudi protitankovske mine. ${ }^{29}$

Po končanemu letalskemu napadu je iz vojašnice Ivana Cankarja proti Logatcu po „tankovski cesti“ odšel 2 oklepni bataljon (20 tankov M-84 in 10 (po drugih podatkih 8) bojnih vozil BVP M-80A). Na prvo oviro je oklepna kolona naletela pri mostu čez Belo na „tankovski cesti“. Barikada, ki je bila narejena iz kupa kamenja in lažnega napisa „minirano“, je kolono zadržala za približno 20 minut, dokler ni bilo ugotovljeno, da sploh ni minirana. Med tem časom so na magistralni cesti Vrhnika - Logatec pri Cesarskemu vrhu naredili barikado iz tam pripravljenih tovornjakov, bagra in drugih vozil, ter nastavili pripravljene protitankovske mine. Barikado sta branila Diverzantski vod TO Logatec in Zaščitni vod TO Logatec, razmeščena nad cesto in železniško progo. Ko so tanki pripeljali do barikade, je prvi tank ustrelil s topom v barikado, ostali tanki so začeli streljati iz mitraljezov, nakar je prvi tank še enkrat ustrelil s topom. Barikade se je nato vnela in vozila so začela goreti, razneslo je tudi nekaj protitankovskih min. Ko je barikada še gorela, je prvi tank zapeljal vanjo in jo poskušal prebiti. Ogenj je zajel gumijaste dela na tanku, zato je posadka tank začela gasiti, nato pa so ga odvlekli ven iz barikade. Na tanke so streljali tudi z ročnimi raketometi, na po-

bljana, 1993), 43-47; Andrej Jurjevič: Naš prispevek k osamosvojitvi-Vod vojaške policije 5. PŠTO (Ljubljana, 2006), 40-41; glej tudi: Brane Praznik: Branilci domovine. Pripoved o teritorialcih v letu 1991 (Ljubljana 2000).

${ }^{28}$ VMSV, ZA, fond 1991:Izvajanje b/d 1. okbr - analiza, Komanda 1. okbr, št. 1206-1, 13. 8. 1991. Verjetno so tako z 2. oklepnim bataljonom želeli zaščititi vojašnico v Logatcu, tankovske čete pa je odšla proti Sinji gorici verjetno zaradi odvračanja pozornosti.

${ }_{29}$ Sanja Remškar: Občina Vrhnika v času vojne za Slovenijo (1991) (Ljubljana, 2007), $88-89$. 
moč pa sta prispela tudi 42. in 43. samostojni vod iz Grčarevca ter prostovoljci, ki so bili oboroženi tudi s protioklepnimi raketometi M80 „Zolja“, ki so jih dobili iz Idrije. Po razmestitvi na položaje so ob 21.15 pripadniki TO ponovno napadli tankovsko kolono, pri čemur so poškodovali dva tanka, iz tankov pa so na njih streljali iz mitraljezov. Tanki se nato niso več približevali barikadi, naslednji dan pa so se začeli vračati v vojašnico, kamor so se vrnili do 20. ure 3. julija 1991. ${ }^{30}$

Čeprav so z barikado uspešno preprečili prodor tankov, so v poveljstvu 53. ObmŠTO dodali: „Splošna ugotovitev na naši strani je, da imamo premalo učinkovitih orožij za protioklepni boj, v začetku prodora smo imeli samo nekaj parov ročnih raketnih metalcev ${ }^{31} \mathrm{z}$ bojnimi kompleti, saj je M-84 s temi orožji možno le delno onesposobiti za delovanje, podobno je tudi z Zoljami. ${ }^{\text {‘32 }}$

Ob 17.40 je vojašnico zapustila 1. tankovska četa 3. oklepnega bataljona (10 tankov M -84) in odšla proti Sinji Gorici. Zaradi izpada tankov so pripadniki TO z raketometom M80 „Zolja“ streljali tudi na poveljstvo 1. oklepne brigade v vojašnici Ivan Cankar. Iz vojašnice so odgovorili z dvema topovskima streloma proti Podčelu, izstreljenima iz tankov, razporejenih nad vojašnico proti Sveti Trojici. Tanki so streljali na barikado pri izvozu iz Vrhnike poti Sinji Gorici in jo zažgali, med gorenjem je razneslo tudi protitankovske mine v barikadi. Poveljnik protioklepnega voda Igor Miklavčič je streljal s raketometom Armbrust na prvi tank iz nadvoza na avtocesto pri Sinji Gorici, tanki pa so začeli streljati nazaj. Tanki so nato obstali pred barikadami, nato pa se začeli ob približno 18.30 vračati proti vojašnici, ker so dobili ukaz o vrnitvi na izhodiščne položaje. Ker je bilo pričakovati nove napade JLA po Vrhniki, je TO začela dovažati okrepitve. ${ }^{33}$

O obeh poskusih prodora so v 53. ObmŠTO zapisali: „Glede na to, da se je na obeh straneh odpiral le manjši ogenj, v času prodora Oklepne brigade na smereh proti Ljubljani (na Vrhniki) in Logatcu (na Pustem polju v Logatcu), ki je imel predvsem za cilj dosego cilja s čim manjšimi žrtvami, so bili ognjeni spopadi bolj opozorilnega značaja. Odločilno vlogo pri blokadah smeri so odigrale ovire-blokade, ki so omogočale realizacijo naših nalog brez izgub in poškodb ljudi na naši strani. Verjetno pa bi do izgub prišlo, če bi enote JA bile enotne in bolj udarne. Enako bi tudi naše enote odgovorile z močnejšim ognjem, kljub slabši opremljenosti in izurjenosti v začetnih bojnih dejstvih z nasprotnikom.“34

${ }^{30}$ Sanja Remškar: Občina Vrhnika v času vojne za Slovenijo (1991) (Ljubljana, 2007), 90-91; VMSV, ZA, fond 1991, škatla 9 : Izvajanje b/d 1. okbr - analiza, Komanda 1. okbr, št. 1206-1, 13. 8. 1991.

${ }^{31}$ Mišljeni so verjetno RB M57.

32 VMSV, ZA, fond 1991, škatla 9: Analiza bojnega delovanja TO 53. ObmŠTO Logatec v času od 26. 6 do 15. 7. 1991, poročilo 53. ObmŠTO za 5. PŠTO št. 804-03147-91 z dne 16. 7. 1991.

${ }_{33}$ Sanja Remškar: Občina Vrhnika v času vojne za Slovenijo (1991) (Ljubljana, 2007), 91-92; VMSV, ZA, fond 1991, škatla 9: Izvajanje b/d 1. okbr - analiza, Komanda 1. okbr, št. 1206-1, 13. 8. 1991.

${ }^{34}$ VMSV, ZA, fond 1991, škatla 9: Analiza bojnega delovanja TO 53. ObmŠTO Logatec v času od 26. 6 do 15. 7. 1991, poročilo 53. ObmŠTO za 5. PŠTO št. 804-03147-91 z dne 16. 7. 1991. 


\section{Zračna obramba v Ljubljanski pokrajini}

Na območju 5. PŠTO je bilo tudi več letalskih napadov. Že prvi dan vojne 27. junija 1991 so enote protizračne obrambe, ki so bile v sklopu varovanja 510. Učnega centra TO na Igu opazovale prelet helikopterjev. Ob približno 18.30 sta nad Igom letela dva helikopterja $\mathrm{Mi}-8$, ko so nanju streljali s protiletalsko raketo Strela 2M. Po ukazu 5. PŠTO je streljal vojak Zoran Dernovšek, ukaz iz 5. PŠTO je posredoval poveljnik 510. učnega centra. Kmalu nato je so zvezo z enoto vzpostavili tudi neposredno iz 5. PŠTO, poveljniku podpolkovniku Mihi Butari so poročali, da so že prejeli ukaz in da bodo odločno delovali. Raketa je zadela enega od helikopterjev, ki je padel na tla nedaleč od Iga. Kmalu zatem ob približno 19. uri so v Ljubljani s stolpnice Iskre vojaki 30. razvojne skupine $\mathrm{z}$ raketo Strela 2M streljali na helikopter SA 341 (Soko H.42) „Gazela“, ki je letel nizko nad Ljubljano. Helikopter je bil zadet in je padel na območje Rožne doline, v razbitinah pa je umrl tudi pilot Anton Mrlak, ki je takrat že sodeloval s TO RS. Za varovanje prestolnice pred novimi napadi so protiletalske enote 5. PŠTO zasedle položaje na Ljubljanskem gradu, vod protizračne obrambe TO Kamnik z dvema lanserjema raket Strela $2 \mathrm{M}$ pa so po ukazu poslali na območje Brnika, kjer mu je poveljevala skupina iz Republiške koordinacije. Vsled naglice in groženj enega od članov poveljujoče skupine strelcema raket je prišlo do nepravilnega lansiranja dveh raket. Ena pa je obtičala $v$ cevi iz neznanega razloga. Nova zračna nevarnost je Ljubljani pretila v nedeljo 30. junija 1991, ko je bil dan alarm za zračno nevarnost, ko so vzletela letala iz letališč JLA po drugih republikah bivše Jugoslavije. Zadnjič so letala JLA preletela Ljubljano okoli 14. ure 2. julija 1991, ko je Mig-21 prebil zvočni zid z namenom zastraševanja ljudi, nato je bil sprožen alarm za zračno nevarnost. ${ }^{35}$

Pri Domžalah pa sta letali Mig-21 že dopoldne nekaj po 11. uri 2. julija 1991 napadli radijski oddajnik. Radijski oddajnik Domžale sta letali obstreljevali za raketami in ga zadeli $\mathrm{v}$ anteno in zgradbo, zadeli sta tudi bližnji daljnovod. Okoli radijskega oddajnika so bile razporejene enote zračne obrambe 55. ObmŠTO, ki pa niso mogle uspešno delovati: „V tem primeru praktično ne moremo govoriti o boju, saj je bil to enostranski napad brez možnosti za uspešno obrambo. Enote, ki so posedale obrambne položaje okrog radio oddajnika niso sprejele podatka o prihodu agresorjevih letal tako, da niso uspeli odgovoriti z ognjem na napad agresorja. PA topovi ${ }^{36}$ enote za PZO so zastareli in neprimerni za dejstvovanje po letalih, ki letijo z nadzvočno hitrostjo. Agresorjevi piloti so nalogo opravili strokovno, ker pa jim ni bilo težko, saj so delovali v idealnih pogojih, zavedajoč se, da jim naše orožje ni bilo nevarno. Z enotami, ki so sodelova-

35 Janez Švajncer: Obranili domovino (Ljubljana, 1993), 231-233; Miha Butara, ustna izjava.

${ }^{36}$ Okoli oddajnika so bili razporejeni proti letalski topovi Flak M30/38 nemškega izvora iz časa druge svetovne vojne. 
le v zavarovanju objekta, objekt ni možno obraniti pred tako oblilo zračnega napada.“37

Zadnji letalski napad je bil napad dveh letal Mig-21 na barikade na Vrhniki, s čimer na bi pomagali ponovnemu izpadu 1. oklepne brigade iz vojašnice „Ivan Cankar“. V torek 2. julija sta nekaj pred 16. uro dve letali iz topov obstreljevali barikade pri bencinski črpalki na Vrhniki in pri Sinji Gorici. Letali sta dvakrat preleteli barikade in jih obstreljevali iz topov. Barikade so uspeli zažgati in pri tem je bilo uničeno več vozil v barikadah. Izstrelki iz letal so ranili štiri domačine, ki so se po naključju znašli poleg barikad. Pripadnike enot zračne obrambe 35 . ObmŠTO so iz vasi Bevke streljali na letali z raketami Strela $2 \mathrm{M}$, vendar ju niso zadeli. ${ }^{38}$

Martin Premk

\author{
SUKOB JNA I TERITORIJALNE ODBRANE \\ SLOVENIJE U LJUBLJANSKOJ POKRAJINI 1991.
}

\title{
Rezime
}

Pisan i zasnovan na arhivskim izvorima i literaturi, članak pruža detaljan pregled sukoba snaga JNA i TO u toku kratkog i oštrog rata u Sloveniji krajem juna i početkom jula 1991. Osnovu članka čine opisi događaja u glavnom gradu Slovenije - Ljubljani i njenoj okolini. Prema predratnoj teritorijalnoj podeli ova zona je bila sedište 5. pokrajinskog štaba TO. Jedinice ovog štaba su, po izlasku snaga JNA i njihovom pokretu prema granicama i važnim objektima u samoj Ljubljani i međunarodnom aerodromu, preuzele ofanzivne akcije, koje su detaljno obrađene u članku. Opisan je sukob sa tenkovskom kolonom kod Trzina, zauzimanje većeg broja vojnih objekata u samom gradu i okolini. Među takve objekte spadaju centar za elektronsko izviđanje na Rožniku i veliko skladište vojne opreme i naoružanja u Borovnici.

${ }^{37}$ VMSV, ZA, fond 1991, škatla 9: Analiza bojnega delovanja TO 55. ObmŠTO Domžale v času od 26. 6 do 15. 7. 1991, poročilo 55. ObmŠTO za 5. PŠTO št. 804-03/36-91 z dne 17. 7. 1991.

${ }^{38}$ Sanja Remškar: Občina Vrhnika v času vojne za Slovenijo (1991) (Ljubljana, 2007), 91-92; VMSV, ZA, fond 1991, škatla 9: Poročilo oletalskemu napadu na Vrhniki Oddelka za kriminalistične zadeve UNZ Ljubljana okolica št. 22/B-13-R-25886/30 z dne 31. 7. 1991. 